\title{
Android-Based Intervention Model for Developing the Religious Identity Status of Late Adolescent
}

\author{
Aulia Diah Pratiwi* \\ Graduate Program \\ Universitas Negeri Yogyakarta \\ Yogyakarta, Indonesia \\ auliadiah.2017@student.uny.ac.id*
}

\author{
Suwarjo \\ Graduate Program \\ Universitas Negeri Yogyakarta \\ Yogyakarta, Indonesia \\ suwarjo@uny.ac.id
}

\begin{abstract}
This work to develops an application of the Android-based intervention model (RIDE) to build the religious identity status of the late adolescent with appropriate and effective criteria. This study used research and development approach with a 4D model with four stages, namely define, design, develop, and disseminate. This research was conducted at Yogyakarta State University with a material expert, a media expert, 10 adolescents for limited trial respondents, and 30 adolescents as extended field test respondents. The data collection techniques used material expert and media expert validation sheets and student evaluation sheets. The data analysis techniques to determine the feasibility and effectiveness of RIDE applications used quantitative descriptive techniques with the categorization approach. The results of the research and development of RIDE applications indicated that RIDE applications become very feasible criteria of the material experts, media experts, and limited trial respondents. The RIDE application was also effective in developing the religious identity status of late adolescent on the expanded field test subjects. Thus, this research and development show that the RIDE application was feasible and effective in developing the religious identity status of late adolescents in achievement.
\end{abstract}

Keywords - android application, religious identity, late adolescents

\section{INTRODUCTION}

Guidance and counseling at the moment are very important to see many challenges that must be faced by students, especially adolescents. Guidance and counseling services intended for adolescents exist in secondary education until early college entry, with an age limit of 14 to 25 years [1]. Adolescence which is also a transition from childhood to adulthood is often referred to as the process of finding an identity. The process is relatively free from responsibility often resulting in the loss of some of the identities they should have [2]. Not infrequently the loss of important identities in adolescents raises juvenile delinquency problems, such as smoking, drug abuse, brawl, free sex, and many more.

UNICEF 2016 data shows that violence among adolescents in Indonesia is estimated at 50\%. Reporting from the Ministry of Health of the Republic of Indonesia 2017 , there are $3.8 \%$ of students who claim to have abused drugs and dangerous drugs (fk.ugm.ac.id, 3/14/2018). The April 2017 case recorded 30 drug abusers involved in the Progo Narcotics operation 2017 and 14 of them were students (Kompas.com, 18/4/2017). Kompas.com (1/6/2017) explained the case of a PTS student in Yogyakarta molested 12 high school students. Another case of teenagers who are very troubling lately is the act of hijacking (begal) or klithih. Mapolda DIY noted that in 2016, cases of klithih in DIY reached 43 cases. The most recent case is the May Day demo riots and the DIY Police set three suspects who are still status as students (Kompas.com, 2/5/2018).

Adolescent problems that are reflected in the cases above become a form of experiments conducted by adolescents in several different roles or behaviors and personalities. Adolescents conducting experiments or exploring the roles and behaviors that exist in themselves will be able to provide experience to them in finding the one role or personality that best suits themselves [2]. Teenagers who are in the process of searching for identity need guidance and support from the surrounding environment so that they are not trapped in a negative experimentation cycle or even experience identity confusion [2]. Guidance and counseling service units in high schools and colleges should be aware that such things will happen to their students or students.

Research conducted [3] on late teens shows that there is a fear of real responsibility that must be carried as an adult, doubts about the ability to overcome these responsibilities, and hopes to achieve a more meaningful life but accompanied by fear will fail. Research from [4] also shows that the transition from late adolescence to early adulthood occurs in several aspects of life, such as confusion in the choice of education, employment, busy work, college, change of residence, unemployment, romantic partners, as well as differences in environmental cultural conditions from high school as students to college as students.

The condition of confusion often experienced by adolescents is called identity confusion [2]. Erikson formulated identity versus identity confusion with the definition of a certain stage of development experienced by individuals during adolescence in establishing social relationships. At this, stage adolescents will be brought together with various roles and various problems about who they are, what is most important to them, and what their life goals are. Adolescents who can survive and face conflicting roles and identities will have a new belief and be able to accept themselves, while adolescents who are unable to overcome the identity crisis will experience identity confusion $[5,6]$.

Marcia [7] is an expert who expands the theory of identity development in adolescence from Erikson and 
draws conclusions about the four status identities in individuals, namely the spread (diffusion), closure (foreclosure), delay (moratorium), and achievement (achievement). The four classifications of identity status reflect the way young people find solutions to identity crises and the division of classes is based on a variety of youth exploration and commitment activities. Papalia \& Feldman [8] states that a teenager who has a diffusion status has no seriousness in calculating choices and avoids being committed. Conversely, individuals who have chosen decisions and are committed to their choices mean that these individuals have reached achievement status [8].

The findings from other studies can also prove a relationship between the status of late adolescent identity with psychological well-being. Adolescents who have mature identities (status achievement) have high scores on aspects of psychological functioning (including internal locus of control, psychological well-being, self-esteem, satisfaction with life, self-adjustment and being realistic), having a positive personality, and have a high level of awareness and emotional stability [9, 10]. Conversely, adolescents with diffusion identity status have low internal control, self-esteem and psychological well-being scores and show a high tendency to engage in antisocial behavior and risk-related behaviors related to health, such as substance abuse.

The identity status of a teenager in one domain can show differences in other domains [11, 12, 13, 14]. A teenager can have identity achievement status in domain $\mathrm{X}$, but diffusion in domain Y. Initially, Marcia [15] only focused on researching three identity domains, namely career, politics, and religion. Then, Grotevant and Cooper [16] expand by adding three other domains (relationships with friends, relationships with girlfriends, and gender roles). Until now, other researchers have continued to develop research on the identity domain and classify these domains into two broad groups, namely ideological and interpersonal $[17,18]$. The ideological domain consists of political, career, moral, and religious domains; while the interpersonal domain consists of the domain of relationships with family, close friends/girlfriends and friends [19, 20, 21, 22].

Marcia [23] explains that one way to determine and select these domains is by assessing the domains that will be very important at that time. The author believes that the religious domain is one of the important domains to be developed in adolescence. Religious identity is something that reflects religious beliefs, attitudes toward religion and spirituality; reflection on religious practices and behaviors; and matters relating to a certain moral and ethical code [2]. A comprehensive understanding of adolescent religious experience is important to be explored given the development of a substantial identity that occurred during late adolescence [24, 25]. Erikson [26] says that adolescence is a period that will experience a period of crisis where they are busy trying to determine their position in the world. An important substance during this process is that adopting a particular belief system (belief) that can provide an understanding of adolescent beliefs about various views about the world and religion is one source of such beliefs [27].
Researchers have also provided evidence of a positive relationship between religious identity and other psychological variables, such as psychological well-being $[28,29]$, self-esteem, the meaning of life and positive affect $[27,30]$ Some of the above studies reinforce the author of the importance of developing an intervention model for the development of the status of religious identity of late adolescents, because, in the late adolescence, individuals are experiencing the process of forming social relationships and choosing important roles for their lives for the future [14]. Religious identity explores what aspects of religious influence the formation and development of individual identities. Like the definition of identity status in general, the status of religious domain identity includes the status of diffusion, foreclosure, moratorium, and achievement [30].

The expert who first developed the ecological theory, Bronfenbrenner said that the theory is a model that conceptualizes the shape of the framework to observe several factors that influence human self-development [2]. Brofenbrenner (1986) also mentions that social contexts that can exert influence on human psychology consist of five layers that are interconnected with each other, namely microsystems, mesosystems, ecosystems, macrosystems, and chronosystems. Of the five layers, the microsystem is the layer closest to the individual and because the closest layer has a great influence on individual development. Microsystem layers include parents, peers, educational environments, and individual residential environments [5].

Other studies have also found a relationship between identity status with the type of interaction and communication carried out in the family and attachment between adolescents and parents. Individuality and connectedness are characteristics of late adolescent families who have achievement status and / or moratorium identity [3]. The emotional attachment aspect of parents is high, but coupled with support for low autonomy is a characteristic of adolescent families who have foreclosure identity status. The environment with a little conflict is also one of the characteristics of adolescent families who have foreclosure status, while low emotional attachment with parents and the provision of minimal independent behavior is a characteristic of adolescent families who have diffusion status [3].

In the context of Guidance and Counseling, this research is expected to be able to increase the theoretical knowledge of the counselor in fulfilling the function of understanding by helping counselees to have a new better understanding of themselves and the environment, such as the family environment, work, education, religious norms, and cultural norms and functions adaptation is to help the counselee to be able to adjust to themselves and the environment dynamically and constructively. Gysbers and Henderson [31] mention that the topic of self-identity is one of the topics included in the counselee's self-development dimension that must be explored by the counselor to develop a comprehensive guidance and counseling program. RIDE application development (Religion, Identity, Dynamic, Energy) based on Android applications that are developed is expected to be one of the new media innovations in providing guidance and counseling services. 
Especially for the private field in tertiary institutions. The RIDE application is also expected to be able to guide users, in this case, late teens to avoid identity confusion but can help in establishing their identity (status achievement), especially in the religious domain.

\section{METHODS}

This research used research and development (R\&D). There are several research and development methods, but the one used in is the 4D (Four D Models) development model from Thiagarajan S., Dorothy S. Semmel, and Melvyn S. Semmel

\section{RESULT AND DISCUSSION}

Result

RIDE application development is carried out with the 4D model development method, namely define, design, develop and disseminate. Stages by stages are passed to create a RIDE application that is used as a medium to develop the status of late-based Android adolescent religious identity. The final product developed is in the form of a RIDE application. RIDE stands for Religion, Identity, Dynamic, Energy. RIDE is an online application that contains an intervention model as outlined in the form of assignments, the scale of the status of late adolescent religious identity to measure the profile of religious identity status before and after the intervention, and reporting on the intervention process during the operation of the RIDE application. RIDE can only be run and operated on smartphone devices with the Android operating system. The purpose of developing this application is to encourage late teens to develop their religious identity status to avoid identity confusion [28]

RIDE has the main content in developing the status of late adolescent religious identity. The main content in this application refers to the intervention model of the development of the status of religious identity according to [31]. The figures mentioned that identity development in individuals consists of three aspects, namely commitment, in-depth exploration and reconsideration of commitment. Commitment is an effort of adolescents in determining choices that are still accompanied by self-confidence born of efforts to determine those choices [32]. In-depth exploration represents the extent to which adolescents can think actively about the commitments they have chosen, reflect existing choices, find additional information about their commitments, and open themselves to willing to discuss with others about these commitments [33, 34]. Reconsideration of commitment refers to a comparison between commitments that have been made now with choices that arise because previous commitments are considered unsatisfactory.

Based on the level of adolescent activity in the aspects of commitment, in-depth exploration and reconsideration of commitment, Crocetti [35] formulate five statuses of religious identity, namely achievement, foreclosure, searching moratorium, moratorium, and diffusion. Achievement status has a high level of commitment and indepth exploration, but a low reconsideration of commitment.
Foreclosure status has a high commitment, but low in aspects of in-depth exploration and reconsideration of commitment. The moratorium status has a low commitment, average in-depth exploration, and high for reconsideration of commitment [36]. Status diffusion has a low commitment, in-depth exploration, and reconsideration of commitment. The status searching moratorium is the opposite of diffusion status, which is high in all aspects of commitment, in-depth exploration, and reconsideration of commitment. The intervention model created and packaged in the RIDE application encourages late adolescents to have a steady status of religious identity or to have a status of religious identity achievement [20]. Thus, in the provision of interventions in the form of this assignment is aimed at increasing commitment based on the results of high in-depth exploration activities, and these activities can reduce reconsideration of commitment $[19,21]$

\section{Discussion}

The feasibility and effectiveness testing of the RIDE application is carried out through expert validation and testing. Expert validation to test the feasibility of the product is carried out by material experts and media experts [37]. Material experts provide a material feasibility assessment of $90.5 \%$, which falls into the "Very Eligible" category. Media experts gave a media feasibility assessment of $92.63 \%$, which was included in the "Very Eligible" category. While the feasibility assessment of the user obtained a score of $80.8 \%$, included in the "Very Eligible" category. So, it can be concluded that the Android-based RIDE application developed is very feasible to use and operate to develop the status of religious identity [3, 38]. The RIDE application presents and provides an intervention model that encourages late teens in developing and accustoming better behavior in a religious context $[39,40]$. The feasibility of interventions in developing good habits (good behavior) is a good way to develop individual abilities in all aspects [41] (Table 1).

Table 1. Recapitulation of Percentage of Eligibility of RIDE Applications

\begin{tabular}{|c|l|l|l|}
\hline Numb & \multicolumn{1}{|c|}{ Subject } & $\begin{array}{c}\text { Percentage of } \\
\text { Feasibility }\end{array}$ & Category \\
\hline 1 & Material Expert & $90.5 \%$ & Very feasible \\
\hline 2 & Media Expert & $92.63 \%$ & Very feasible \\
\hline 3 & College student & $80.8 \%$ & Very feasible \\
\hline \multicolumn{2}{|c}{ Average } & $87.97 \%$ & Very feasible \\
\hline
\end{tabular}

The categorization of the status of religious identity shows that the profile of the adolescent's religious identity status after being intervened through assignments in the application has increased (Palotzian \& Park, 2013: 354). The initial religious identity status before getting intervention showed that 23 students $(76.67 \%)$ had a religious identity status searching for a moratorium and 7 students $(23.33 \%)$ others had a status of religious identity achievement. Meanwhile, after re-measuring their religious identity status after getting intervention, as many as 6 students (20\%) had a religious identity status searching for a moratorium and another 24 students $(80 \%)$ had a status of religious identity achievement (figure 1). 


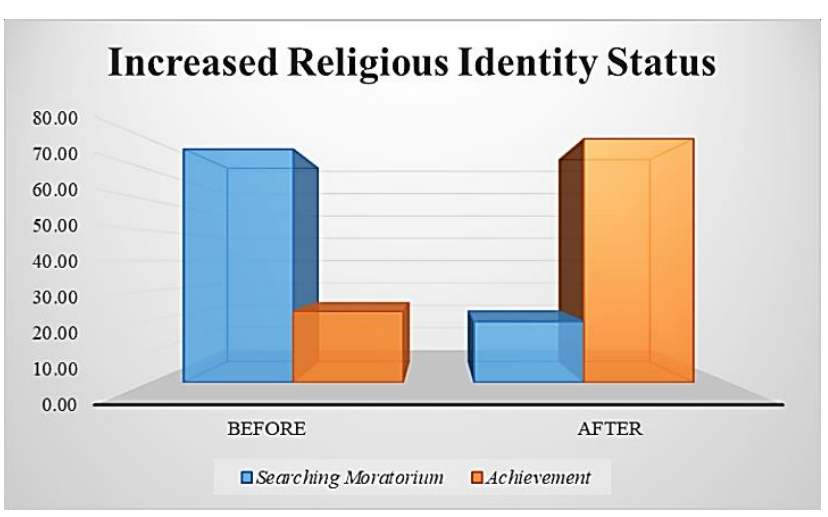

Fig. 1 Increased Religious Identity Status

The data shows that the RIDE application effectively improves the status of late adolescent religious identity to be better than searching a moratorium to achievement $[13,42]$. Based on the results of the research and development of Android-based RIDE applications to develop the status of the religious identity of late adolescents, late adolescents of application users have been able to improve the status of religious identity that they have become more stable $[43,44]$.

\section{CONCLUSION}

This research shows that the profile of the status of the religious adolescent's religious identity after being intervened through assignments in applications has increased. The initial religious identity status before getting intervention showed that 23 students $(76.67 \%)$ had a religious identity status searching for a moratorium and 7 students $(23.33 \%)$ others had a status of religious identity achievement. Meanwhile, after re-measuring their religious identity status after getting intervention, as many as 6 students $(20 \%)$ had a religious identity status searching for a moratorium and 24 students $(80 \%)$ others had a status of religious identity achievement. So, the RIDE application effectively improves the status of late adolescent religious identity to be better than searching a moratorium to achievement.

\section{ACKNOWLEDGMENT}

For further researchers can make similar media to intervene individuals can be given enough time for the implementation of the intervention. It is recommended that trials and field tests can be done in more than one place or university so that the conclusions of the research results can be generalized.

\section{REFERENCES}

[1] Monks, F.J., A.M.P. Knoers. Psikologi Perkembangan Pengantar dalam berbagai bagiannya. Yogyakarta: UGM Press. 2006

[2] Upton, Penney. Psikologi Perkembangan. Jakarta: Erlangga. 2012.

[3] Kroger, Jane. Identity Development, $2^{\text {nd }}$ Edition. California: Sage Publication, Inc. 2011.

[4] Howard, A. L. \& Galambos, N. L. Transitions to Adulthood. Encyclopedia of Adolescence, Volume 1. 2011.

[5] Santrock, J. W. Adolescence (15th ed.). New York: McGraw-Hill Education. 2014
[6] Kamalova, O., \& Andramanova, VV. Problems of Development and New Forms of Identity. Proceeding of Actual Problems of Science: From Theory and Practice. Veteran Publisher, 200-205. 2016.

[7] Marcia, J. E. A commentary on Seth Schwartz's review of identity theory and research. Identity: An International Journal of Theory and Research, 1,59-65. 2001.

[8] Papalia, D. E., \& Feldman, R. D. Menyelami Perkembangan Manusia. Jakarta: Salemba Humanika. 2015.

[9] Schwartz, S. J., Beyers, W., Luyckx, K., Soenens, B., Zamboanga, B. L., Forthun, L. F., Hardy, S. A., Vazsonyi, A. T., Ham, L. S., Kim, S. Y., Whitbourne, S. K., \& Waterman, A. S. Examining the light and dark sides of emerging adults' identity: A study of identity status differences in positive and negative psychosocial functioning. Journal of Youth and Adolescence, 40,839-859. 2011.

[10] Meeus, W. The study of adolescent identity formation 2000-2010: A review of longitudinal research. Journal of Research on Adolescence, 21, 75-84. 2011

[11] Dellas, M., \& Jernigan, L. P. Affective personality characteristics associated with undergraduate ego identity formation. Journal of Adolescent Research, 5, 306-324. 1990

[12] Pastorino, E., Dunham, R. M., Kidwell, J., Bacho, R., \& Lamborn, S. D. Domain-specific gender comparisons in identity development among college youth: Ideology and relationships. Adolescence, 32 (127), 559-577. 1997.

[13] Fadjukoff, P., Pulkkinen, L., \& Kokko, K. Identity processes in adulthood: diverging domains. Identity: An International Journal of Theory and Research, 5, 1-20. 2011.

[14] Beyers \& Goossens. Dynamics of perceived parenting and identity formation in late adolescence. Journal of Adolescence, 31, 165-184. 2011.

[15] Marcia, J. E. Development and validation of ego-identity status. Journal of Personality and Social Psychology, 3, 551-558. 1966.

[16] Grotevant, H. D., Thorbecke, W., \& Meyer, M. L. An extension of Marcia's identity status interview into the interpersonal domain. Journal of Youth and Adolescence, 11, 33-47. 1982

[17] Grotevant, H. D., \& Adams, G. R. Development of an objective measure to assess ego identity in adolescence: Validation and replication. Journal of Youth and Adolescence, 13, 419-438. 1984

[18] Bartoszek \& Pittman. Profiles of Identity Exploration and Commitment Across Domain. Journal of Child and Family Study, 19:444-450. 2011

[19] King, P.E., Clardy, C.E, \& Ramos, J.S. Adolescent Spiritual Exemplars: Exploring Spirituality in the Lives of Diverse Youth. Journal of Adolescent Research. 29(2). 186-212. 2013.

[20] King, P.E., \& Boyatzis, C.J. Religious and Spiritual Development. Socioemotional Process Journal, 3, 183-192. 2015.

[21] King, P.E., Carr, D., \& Boitor, C. Chapter 7 - Religion, Spirituality, Positive Youth Development, and Thriving. Journal of Advances in Child Development and Behavior. 41. 161-195. 201).

[22] Kim, S., \& Esquivel, G.B. Adolescent Spirituality and Resilience: Theory, Research, and Educational Practices. Journal of Psychology in the Schools. 48(7). 755-765. 2011.

[23] Marcia, J. E. A commentary on Seth Schwartz's review of identity theory and research. Identity: An International Journal of Theory and Research, 1,59-65. 2001.

[24] Wright, E. W, Jr. Erikson: Identity \& religion. New York: The Seabury Press. 1982

[25] Fowler, J. W., \& Dell, M. L. Stages of faith from infancy through adolescence: Reflections on three decades of faith development theory. Dalam E. C. Roehlkepartain, P. E. King, L. Wagener, \& P. L. Benson (Eds.), The handbook of spiritual development in childhood and 
adolescence (pp. 34-45). Thousand Oaks, CA: Sage Publications. 2006.

[26] Erikson, E.H. Childhood and Society. New York: Norton. 2011

[27] Davis, R. F., \& Kiang, L. Religious Identity, Religious Participation, and Psychological Well-Being in Asian American Adolescents. Journal of Youth and Adolescence, 45, 532-546. 2016.

[28] Lewis, C. A., Maltby, J., \& Day, L. Religious orientation, religious coping, and happiness among UK adults. Personality and Individual Differences, 38, 1193-1202. 2011.

[29] Abu-Rayya, M. H., \& Abu-Rayya, H. M. Ethnic identification, religious identity, and psychological well-being among Muslim and Christian Palestinians in Israel. Mental Health, Religion \& Culture, 12, 147-155. 2011.

[30] Chan, M., Tsai, K. M., \& Fuligni, A. J. Changes in religiosity across the transition to young adulthood. Journal of Youth and Adolescence, 44 (8), 1555-1566. 2014

[31] Gysbers, \& Handerson. Developing and Managing Your Schoo Guidance and Counseling Program, Fifth Edition. Alexandria: ASCA. 2011.

[32] Crocetti, E., Rubini, M., Luyckx, K., \& Meeus, W. Identity Formation in Early and Middle Adolescents from Various Ethnic Groups: From Three Dimensions to Five Statuses. Journal of Youth and Adolescence, 37, 983-996.2011.

[33] Klimstra, T. Adolescent Personality Development, and Identity Formation. Journal of Child Development Perspectives. 7(2). 80-84. 2012.

[34] Crocetti, E., Klimstra, T.A., Hale III, W.W., Koot, H.M., \& Meeus, W. Impact of Early Adolescent Externalizing Problem Behaviors on Identity Development in Middle to Late Adolescence: A Prospective 7 Year Longitudinal Study. Journal of Youth and Adolescence. 42(11) 1745-1758. 2013.

[35] Crocetti, E., Erentaite, R., \& Zukauskiene, R. Identity Styles, Positive Youth Development, and Civic Engagement in Adolescence. Journal of Youth and Adolescence, 43(11). 1818-1828. 2014.
[36] Hardy, S. A., White, J. A., Zhang, Z., \& Ruchty, J. Parenting and the socialization of religiousness and spirituality. Psychology of Religion and Spirituality, 3(3), 217-230. 2011.

[37] Ray, D.C. Single-case Research Design and Analysis: Counseling Applications. Journal of Counseling \& Amp Development, 93(4), 394 402. 2015.

[38]Frey, L. L. Relational-cultural therapy: Theory, research, and application to counseling competencies. Professional Psychology: Research and Practice, 44(3), 177-185. 2013

[39] Nwanodi, O., Salisbury, H., \& Bay, C. Multimodal Counseling Interventions. Journal of Obstetrics and Gynecology. 3. 127-136. 2016.

[40] Fuji, H., Yokoyama, T., Yoshimi, I., \& Mizushima, S. A Randomized Controlled Trial to Evaluate the Effect of Health Guidance with Video Call as Compared to Face-to-face Health Guidance. International Medical Journal, 24(2), 186-191. 2017.

[41] Alex, H.K., Linda, J.B., Jodi, S.H., Melanie, R.W., Kurt, C.S., \& Meghan, W. Evaluating Feasible and Referable Behavioral Counseling Interventions. American Journal of Preventive Medicine. 49. 138-149. 2015

[42] Rajeesh, E., \& Anupama, M. Social Media and Data Mining Enable Pre-counseling Session: A System to Perk Up Effectiveness of Counseling in Distance Education. Proceedings of the International Conference on IoT In Social, Mobile, Analytics and Cloud, I-SMAC, 153-156. 2017.

[43] Althoff, T., Clark, K. \& Leskovec, J. Large-scale Analysis of Counseling Conversations: An Application of Natural Language Processing to Mental Health. Transactions of the Association Computational Linguistics, 4, 463-476. 2016.

[44] Michaelson, V., Brooks, F., Jirasek, I., Whitehead, R., King, N., Walsh, S., Davison, C.M., Mazur, J., \& Pickett, W. Developmental Patterns of Adolescence Spiritual Health in Six Countries. SSM Popul Health Journal, 2, 294-303. 2016. 